\title{
The Book of Nadath
}

Reviewed by Jane Stafford, Victoria University, Wellington

\author{
The Book of Nadath. \\ Robin Hyde. \\ Edited by Michele Leggott. \\ Auckland: Auckland University Press, 1999.
}

Robin Hyde wrote The Book Of Nadath during 1937, a prolific period for her, in which she completed The Godwits Fly, worked on Nor the Years Condemn, and began the autobiographical A Home in This World. When she went to China in early 1938 she may have taken a copy of Nadath with her, and a copy may have been left with her mother. After her death in London in August 1939, her papers were returned to New Zealand, and ended up in the care of Rosalie and Gloria Rawlinson. In 1947 Gloria Rawlinson prepared an edition of Hyde's poems, Houses by the Sea and the Later Poems (Caxton Press, 1952), intending to follow this volume by a second, to include longer pieces, including The Book of Nadath. A typescript and introduction were submitted to Caxton, and later (late 1958 or early 1959), to Louis Johnson, then proprietor of the Capricorn Press, but the work never appeared. In 1951 Hyde's son Derek Challis took over literary executorship, and his papers were deposited in the Auckland University Library in 1961. There were three versions of The Book of Nadath-a manuscript, Hyde's typed copy with hand-written corrections, and a carbon copy of Rawlinson's typed somewhat modified transcription.

Michele Leggott's edition combines these, and also takes into account two draft fragments. The typescript that Rawlinson gave to Johnson, found by Leggott in his papers in the Turnbull as she was completing the editing process (surely an editor's worst nightmare), is referred to but not used, as it is substantially the same as the carbon copy version. But Rawlinson's introduction is included as an appendix. Leggott has made some reasonable editorial assumptions, chiefly concerning the break-possibly from lost or damaged pages-towards the end of Hyde's typed version. Rawlinson-incorrectly, Leggott feels-conflates two sections, where she no longer has Hyde's typescript as template, and ignores the evidence of the manuscript. Leggott has reconstructed what she feels is a preferable reading of these sections using the manuscript as base text. The manner in which the text is set out, with courier type indicating material sourced from the manuscript, and endnotes giving

Kōtare 2, no. 2 (1999), pp. 82-86. 
alternative readings from whatever version is not being used in the main text, is exemplary. We feel that we are reading a poem, restored to its textual integrity, rather than, as is in fact the case, encountering an intricate, complex and highly scholarly piece of reconstruction.

Leggott is not as successful in the contextualisation she gives to The Book of Nadath. Her introduction is lengthy and detailed. While there is a good deal of interesting autobiographical material, and lengthy reference to other Hyde poems, there is little attempt to explain what the work is: or its relationship to the literary tradition. We are invited to view it as something beyond such influences. Yet influences there are, interesting ones: the Bible, of course- $\underline{\text { Hyde described }}$ her work as like the Scriptures 'only of course more elevated'. But any nineteenth- or twentieth-century author who configures their work in terms of scriptural cadences is surely working out of Blake, 'The Marriage of Heaven and Hell', 'The Book of Thel', or 'The Vision of the Daughters of Albion'. Shelley seems to me a strong influence, in the politically inflected prose works, but especially in his long poem 'Alastor', whose vaguely delineated persona and dreamlike quasi-metaphorical wanderings are very close to the tone and style of Nadath. Both Shelley and Blake would have commended themselves to Hyde as part of that counter-canon of British radical literature, which, as Stuart Murray has pointed out (Never a Soul at Home, 1998), was an important influence in left-wing circles here. Whitman is another obvious influence, and Pound and Eliot seem insistently present. The Waste Land, with its complex form involving discrete sections which can nevertheless be read as parts of a whole, its shifts in tone and narrative position, its layerings of apocalyptic, political, personal and spiritual fragmentation-all these seem obviously part of Nadath's ancestry. The Indian connection, seen most insistently in the section entitled 'The Three Who

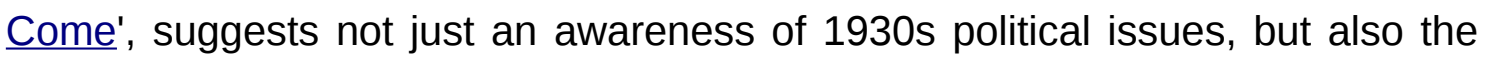
connection of the work to that nexus of eastern spiritualism and western occultism current in late nineteenth and early twentieth century poetry. Poets such as Yeats are an obvious link here. Leggott refers in the introduction in passing to Kahlil Gibran's The Prophet (1923) and briefly in footnotes to Krishnamurti and Tagore. These connections seem to me very suggestive, and worth following up. Tagore's 1914 novel was called The Home and the World, a possible parallel to the title of Hyde's autobiographical work, $\underline{A}$ Home in This World.

Several sections of The Book of Nadath have a strong New Zealand and Maori referent, yet Leggott seems to resist seeing the poem as part of the literary nationalism of the thirties. I feel this needs to be argued. Fairburn's 'Dominion' is not perhaps as unlike Nadath as Leggott suggests. It is just that

Kōtare 2, no. 2 (1999), pp. 82-86. 
Nadath seems less modern and modernist, more reminiscent, perhaps, of the Maoriland writers of the turn of the century, with their construction of the local in a synthesis of Maori myth, Victorian Romanticism and eastern-influenced occultism. Leggott's discussion of Hyde's use of the figure of lo, a conflation of Maori and classical sources, is interesting, but we should note that this was not a new association. Jessie Mackay's poem 'The Noosing of the Sun-God' (New Zealand Verse, ed. Alexander and Currie, 1906,144) talks of 'lo, the Nameless, the Father, /To whom the eyes pray/ But whom the tongue names not.' Hyde may have talked disparagingly of Maoriland's ornamentational use of Maori motifs, but she read their work and may have been more sympathetic to their purpose than previously allowed.

Does Leggott exclude these authors-or much discussion of influence beyond the obvious-because they are not the kind of context she wishes to see Nadath in? Or is it because influence itself conflicts with her view of Hyde's genius as self-generating? The critical reading of the poem displayed in the introduction seems to view Hyde's work as a seamless unity, any part of which can illuminate any other part. This leads to some odd assumptions, in particular, a suggestion in the introduction that, in the place where there is a break in Hyde's typescript, we can substitute verses cut from an entirely different poem, justifying this with the principle 'Let one textual disappearance speak for another.' This is not the technique Leggott has followed in her scrupulously orthodox editing process, so what are we to make of it? Is it a suggestion that we modify our reading practices, that we imaginatively create our own text? In which case, why do we need the authority of hers?

An uneasy fusion of poetic practice and scholarly criticism seems widespread in this introduction, leading to a muddy and often misleading argument. For example, what does Leggott mean when she describes Nadath's 'formal oddity, poem [sic] doing prose work, resolutely unmoderm in its address to the modem condition' but then says it is 'odd, moving, lyrical, ahead (out of joint with) its time'. Can it be both ahead and unmoderm? What does it mean to describe the work as 'flickering impersonation'. Of what? Why flickering? Can one say that the poem both 'belongs to and enlarges' Hyde's other poetry and that she 'worked deep moral convictions in each but to different ends'? Do sentences like 'Nadath, the false prophet anagrammatically at hand, Hebraically (nadach) expelled, slipped or moved away, had spoken truth and the mark of it endured in dust' mean anything? What about the sentence, 'The poem is delirious; it sets out with no undertaking to be truthful but may of course speak truth in delirium, a late-come wisdom text struggling with ideas about wisdom'? Does this contain any critical judgement or is it literary mysticism?

Kōtare 2, no. 2 (1999), pp. 82-86. 
There does seem to me to be an assumption contained in these passages that has real critical force and is at the same time highly arguable. Leggott would like to read The Book of Nadath as an unstable text, not just historicallyin the sense that Hyde may not have finished it and certainly did not prepare it for publication-but in essence. Hyde's typescript contains problems-the first 16 pages are numbered continuously, but the remaining pages are numbered within the sections. Thus after page 16 there is no assurance that the order of the sections is fixed or correct. But can this be reasonably interpreted to mean, as Leggott argues, that Hyde 'gave up on linear decorum and gave in to the lateral reach of Nadath', that 'she became fascinated by the field of its discontinuous narrative' and that 'there are two Nadaths and there is in each case one place to start reading but very soon there is the pleasure (or anxiety) of choosing a path through the sections and responding to that version of narrative events'? (Why two? Doesn't this position open the possibility of multiple reading, even infinite readings?) This point is reiterated as the introduction concludes: 'A god, a woman and a poem may have two titles, two versions, and two fates; one visible, another obscure. There are two Nadaths, one printed here not without crucial assistance from the other.' Leggott then goes on to suggest that the millennium is an auspicious time for Nadath to appear, to describe the auguries that Hitler witnessed at the signing of the NaziSoviet Pact, and concludes 'But now the other prophesying woman will be heard, and the words will be spoken for a memorial of her. There are always two versions'.

In his 1969 essay, 'Printers of the Mind' (Studies in Bibliography, ed. Fredson Bowers, 2), Don McKenzie quotes Karl Popper quoting a nineteenth century scientist: 'A nice adaptation of conditions will make almost any hypothesis agree with the phenomena. This will please the imagination, but does not advance our knowledge.' There are two versions of this edition of Robin Hyde's The Book of Nadath. One is an exemplary work of scholarly detection, preparation and presentation. The other is a work of the imagination.

Kōtare 2, no. 2 (1999), pp. 82-86. 